\title{
Impact of COVID-19 on Informal Economy: The Revival
}

\author{
Jeemol Unni ${ }^{1}$
}

Published online: 16 September 2020

(c) Indian Society of Labour Economics 2020

\section{Introduction}

According to the Centre for Monitoring Indian Economy (CMIE), an estimated 122 million people lost their jobs in April 2020 alone and three-quarters of these were small traders and wage labourers, mainly in the informal sector (Thomas 2020). Estimate from the PLFS 2017-18 showed that of 471 million workers nearly $21 \%$ were self-employed. Casual labourers in agriculture were estimated at 50 million and 64 million in non-agriculture in 2018. Thomas computes the labour share of income in the GDP at 30\% in 2018. Extrapolating from the 2018 figures, Thomas makes a bold estimate of loss of Rs. 4 lakh crores of income among the vulnerable workers in the 2 months of lockdown since 25 March 2020 (Thomas 2020). Further, according to Pranob Sen, Chief Statistician of India, unemployment rates are expected to rise to $8.5 \%$ in the financial year 2021 (Suneja 2020).

Whatever the estimate of loss of GDP, our interest is in the income loss and suffering of the workers and their households and the compromises they make to survive the crisis. Forecasts and estimates are useful. However, policy-making also requires a deep dive down into the micro-context of who, what, where, why and how, in a disaggregated fashion, to reach and benefit the concerned workers and enterprises. In this brief paper, I touch on some of these micro-issues concerning enterprises and workers and certain short-term and medium-term strategies for revival of the economy.

\section{Micro-Enterprises}

India recorded 63 million MSME, ${ }^{1}$ employing 107 million people, in 2018-2019 (Government of India 2020). The Economic Census (EC), 2013, estimated that $72 \%$ were own account enterprises that did not hire workers on a regular basis and

\footnotetext{
1 Micro, Small and Medium Enterprises (MSME).

Jeemol Unni

jeemol@gmail.com

1 Ahmedabad University, Ahmedabad, India
} 
operated with their own family labour. Of the total enterprises, EC 2013 estimated that nearly $36 \%$ were operated from household premises. The small scale of operation of such micro-enterprise, own account and home based, makes them particularly vulnerable to an economic shock such as the lockdown.

A recent survey by All India Manufacturers' Organisation (AIMO) in association with nine other industry associations, conducted during 24-30 May 2020, noted that a third of the self-employed, small and medium enterprises were on the verge of closing down (Magazine 2020a, b). In the AIMO Survey of 42, 525 MSMEs, 32\% of the respondents felt their units were beyond recovery and $29 \%$ said it would take 6 months to recover. A former president of AIMO stated that the reason for closure of units was not the recent crisis alone, but earlier demonetization and implementation of GST over the last 3 years and the economic slowdown which had already left them stressed (Magazine 2020a).

Change in definition of MSME: A day after Unlock 1.0 the Union Cabinet approved an economic package for MSMEs with an expanded definition to allow higher investment limits. A disturbing feature of the expansion of the definition of MSME is that with rise in the upper limit of the definition of MSME the balance of resources will tilt in favour of larger enterprises. The change in definition of MSME also includes an increase in turnover limits to 250 crores. This was done to cater to the demand of the larger enterprises where the investment in machinery may not be high, but because of expensive raw material, their turnover is high (Saluja 2020). The idea apparently is to allow the enterprise at the upper limit of the definition to grow and yet obtain the benefits of the scheme. However, what was the need to do this now when all enterprises and particularly the genuinely micro-enterprises are stressed?

Credit to MSME: For the micro-enterprises, the government announced Rs. 4000 crores, out of the total of Rs. 20,000 crores to a Credit Guarantee Fund Trust for Micro and Small Enterprises. Stressed enterprises whose loans have been classified as Non-Performing Asset (NPA) will be eligible for supplementary credit by banks against a partial credit guarantee by the government. This should encourage banks to lend to these small enterprises that are indebted to them already. It is reported that the Public Sector Banks have started sending messages of pre-approved loans at attractive rates to prime retail customers (Sikarwar 2020).

Where does this leave the micro-enterprises that are hit by the 2 months of lockdown and the $32 \%$ of MSME preparing to close down? The enterprises that were not indebted to the formal sector banks, but to local moneylenders and other friends and family as is the main source of credit to micro-enterprises, are left high and dry. Almost in response to this criticism, the government has extended the Emergency Credit Guarantee Scheme to enable lending to individual entrepreneurs (Verma 2020). Truck operators and a large proportion of small enterprises are run by such individual entrepreneurs who take loans in their personal names. Hopefully, this will revive the cargo transport sector and micro-enterprises.

Backward Linkages: The government has been criticized for viewing the crisis as a supply side problem. Increasing liquidity has been the focus through credit schemes and reduction in interest rates. Interest rates were reduced even before the pandemic with no effect due to the slowdown in the economy. The supply side 
problem that now needs to be addressed is the backward linkage for the MSMEs. Sridhar (2020) described how the production linkages had been disrupted with the closure of all economic activity due to complete lockdown. To revive the economy, many inter-related sectors have to start operations. Besides raw materials, labour supply may also be a concern with the large reverse migration. Food and textile industries may be better off if they source only primary products from agriculture as inputs. The transport industry has to become fully functional with free interstate movement.

Powerloom: The powerloom industry may be taken as a classic example of clusters of MSME, ranging from small, medium and even large enterprises. The clusters of powerloom are concentrated in Malegoan and Bhiwandi in Maharashtra, and Surat in Gujarat. This industry spins yarn into a rough grey cloth which is then processed further in other sectors. A majority of the workers are migrants in Bhiwandi and Surat, though a large proportion of workers is local in Malegaon. With the state governments allowing partial reopening, a few powerloom units reopened in the first week of June, but with a major constraint of labour as the majority of migrants had returned to their hometowns. Further with supply chains broken, both backward and forward linkages, for raw material and finished goods, respectively, are a constraint (Shaikh 2020). Strangely, Shaikh (2020) reported that the sectors that had installed new automated powerlooms were finding it more difficult to operate, as these looms required trained workers who were mainly migrants. The units cannot become fully operational till the major part of the economy becomes functional.

Labour Laws: Some states have suspended labour laws for a period in the hope that it will encourage industries to reopen after lockdown is lifted. Unni opined that 'cost of labour is not the most important component of overall costs, except perhaps in some labour intensive industries. Whittling down the few benefits that exist for labour is not going to help industry in the long run. Only a more productive labour force can increase profits and in turn the growth rate of GDP' (Quoted from an interview, Joshi 2020). Prabhu and Mehta (2020) had a very interesting observation, 'Labour should be considered a form of capital (and) every worker should be evaluated in terms of share and workers should be raised to the status of shareholders'.

\section{Trade}

Another sector that may have to change its strategy is the trade and marketing division of all large and small enterprises. In an interview, the soft drink giant Rasna's Chairman and Managing Director said 'business is never going to be the same again' (Misra 2020). The pandemic has affected this market as there are no guests, wedding ceremonies or parties where a welcome drink is served. He anticipated a large cut in sales staff as face-to-face selling would decline. E-commerce, Amazon and Flipkart, may become the reality in the FMCG market.

Street Vendors In the context of lockdown, we can distinguish three categories of street vendors. The prospects of these three categories of street vendors vary:

Group 1: Trade in 'essential' commodities: Vendors that trade in 'essential commodities' such as fruits and vegetables can operate if they have their vendor licence 
and additionally may require a health permit. All normal barriers to entry may apply here as well.

Group 2: Trade in 'semi-essential' commodities: Street vending in food is under the scanner due to reasons of health and hygiene. However, this is an essential trade as many persons who stuck in town need a source of cooked food. Their situation is precarious and likely to remain so even after the lockdown is lifted as concerns of hygiene, permits under FSSA Act, social distancing and decline in demand will hit them.

Group 3: Trade in 'non-essential' commodities: Vendors of non-essential commodities, such as cloth and plastics, are in the most precarious situation as both their demand and supply are compromised. Demand is hit due to lack of money in circulation and supply due to closure of units producing these commodities, the backward linkages.

The chances of revival for these three segments of street vendors would be different, and therefore, any plans for revival should consider this.

\section{The Revival}

Categories of workers and enterprises: The resurrection plan has to consider two categories each of workers and enterprises. Among workers, the needs of wage and salaried workers, including migrants, are different from the self-employed workers. Among enterprises, a distinction has to be made between own account micro-enterprises and establishments, small and medium enterprises. There is a major overlap between the self-employed workers and the own account enterprises. Hence, for revival of the economy we can group these into three categories: (1) wage and salaried workers, (2) self-employed own account enterprises and (3) small and medium enterprises. A large part of the existing stimulus package is aimed at the third category of small and medium enterprises. The revival plan has to consider each of these three groups separately. Again, even within these three broad categories also, one would need to distinguish between the more vulnerable from the rest, for example, the casual workers, including being migrants.

Restructuring of industry: Possibility of large-scale reallocation of resources, investment and workers leading to restructuring of economic activities exists. Industries where demand is perceived not to revive may face closure. There was a time in the early phase of liberalization when we spoke of sunrise and sunset industries and considered how to move resources and labour from the sunset to the sunrise industries. It might be a useful exercise for the Ministry of MSME to undertake a review of which industries are likely to collapse completely or partly and which are likely to zoom ahead. There is need for a perspective plan or road map, perhaps from NITI Aayog, on this issue of restructuring.

Restoring Backward-Forward Linkages: The supply chain has to be restored, backward-forward linkages opened. Till then, recovery will be partial. Revival of the MSME sector requires more than what is promised in the stimulus package. A possibility is a special stimulus with focus on some clusters of industries, such as the powerloom sector, that is labour intensive and engages a large proportion of migrant 
labour. Encouraging, incentivizing and coaxing the migrant workers to return would also mean ensuring some health and occupational safety cover for the workers.

Bridging the Digital Divide: With much of commerce and services moving online, bridging the digital divide is required: (1) nation-wide internet connectivity, if not rural areas and small towns will be left behind; (2) to produce affordable smartphones, tablets and laptops, if not women and young will be left behind; (3) affordable data charges and broadband, if not the poor will be left behind.

Addressing Skill Mismatch: In the medium term, upgrading the skills of workers to engage them in related but higher-level occupations will give them more income and also reduce chance of dismissal. To plan for workers based on their skills, lack of data on skills of workers is a major constraint. Here we find ourselves in shaky territory as there is no clear mapping of skill of workers. Skill involves both formal certified skills and informal skills learnt on the job. To start small, one can identify many local-level efforts in cities that map skill of workers digitally. In Bengaluru, Teamlease $^{2}$ has been a pioneer in recording informal workers and their skills digitally. There are many such initiatives in Gurugram, Delhi, Ahmedabad and other cities. Recognizing and listing such organizations are a first step. The next step would be to compile a list of such informal workers and their skills from all these microefforts. Once this process begins, many more such local initiatives will come to light. With mobile numbers of these workers, one can conduct a verification of their current location and updated skills. This could be major initiative towards visualizing a strategy for skilling and deploying these workers.

Similarly, an effort to digitalize the demand side of skill requirements of the industry located in industrial estates is required. As medium-term plan, a nationallevel mapping of demand and supply of skills can help to a large extend to identify the problem of skill mismatch. The next step would be to organize skill training for the eligible, classified by existing skills, in the areas where demand exists.

To sum, we do require macro-level forecasts and estimates of loss of employment, incomes and GDP. This will help in macro-planning of budgets and allocation of resources. However, to successfully plan a revival of the economy, micro-level understanding of the situation is essential. This will help to visualize a plan of action and policies in the short and medium term and how to galvanize the workers and enterprises.

\section{References}

Government of India. 2020. MSME Annual Report 2018-19, New Delhi.

Joshi, Gunjan. 2020. Suspension of Labour Laws and Cutting Down Few Benefits' Interview to Edu-

Almanac, June 6, 2020 http://www.edualmanac.com/2020/06/06/suspension-of-labour-laws-andcutting-down-few-benefits-would-discourage-labourers-more/.

Magazine, Aanchal. 2020a. 'One in Three Businesses Close to Winding Up', Indian Express, June 2.

\footnotetext{
${ }^{2}$ https://www.teamlease.com/.
} 
Magazine, Aanchal and Anil Sasi. 2020b. Rs. 3 lakh crore relief package for MSMEs but government, private firms owe them more, Indian Express, May 25 https://indianexpress.com/article/india/rs3-lakh-crore-relief-package-for-msmes-but-govts-pvt-firms-owe-them-more-6410442/.

Misra, Leena. 2020. 'Business is Never Going to be the Same Again...Will Have to Cut Down on Sales Manpower': Rasna Chairman, The Indian Express, June 6.

Prabhu, Suresh P and Pradeep S Mehta. 2020. Atmanirbharatvarsh, The Economic Times, July 4.

Saluja, Nishtha. 2020. "Medium Co Turnover Limit may be Doubled for MSME Benefits", Economic Times, May 26.

Shaikh, Zeeshan. 2020. 'Safegaurds for Workforce Lost in Clatter of Powerlooms in Malegaon', Indian Express, Reports from the Field, June 7.

Sikarwar, Deepshika. 2020. PSBs luring MSMEs with pre-approved loans, The Economic Times, June 6 https://economictimes.indiatimes.com/industry/banking/finance/banking/psbs-luring-msmes-withpre-approved-loans/articleshow/76223884.cms.

Sridhar, V. 2020. An Empty Package, Frontline, June 5.

Suneja, Kirtika. 2020. Jobless Rate to Hit 8.5\% if Stimulus Not Widened: Sen, Economic Times, June 6.

Thomas, Jeyan Jose. 2020. India's poor may have lost Rs 4 lakh crore in the coronavirus lockdown, Scroll. in, June $5 \mathrm{https} / / /$ scroll.in/article/963284/indias-poor-may-have-lost-rs-4-lakh-crore-in-thecoronavirus-lockdown.

Verma, Sunny. 2020. Govt's new MSME push: Providing credit to individual entrepreneurs, The Indian Express, July 4 https://indianexpress.com/article/business/economy/govts-new-msme-push-provi ding-credit-to-individual-entrepreneurs-6489049/.

Publisher's Note Springer Nature remains neutral with regard to jurisdictional claims in published maps and institutional affiliations. 